\title{
The Antioxidant Role of Mulberry (Morus alba L.) Fruits in Ameliorating the Oxidative Stress Induced in $y$-Irradiated Male Rats
}

\author{
R. G. Hamzaa*, A. N. El Shahat and H.M.S. Mekawey \\ Food Irradiation Research Department, National Centre for Radiation Research and Technology (NCRRT), Atomic Energy Authority, Nasr City, Cairo, Egypt
}

\begin{abstract}
Based on the radioprotective effect of substance possessing antioxidant effect previously reported, it was hypothesized that mulberry fruit, a substance possessing antioxidant activity, might be able to protect against oxidative stress induced by $\mathrm{Y}$-rays. Gamma-irradiation $(2.5 \mathrm{~Gy} \times 3$ delivered every other day) resulted in a significant decrease in hepatic Glutathione contents (GSH), Xanthine Dehydrogenase (XDH), Superoxides Dismutase (SOD) and Catalase (CAT) activity, the level of insulin and testosteroneC as well as the concentration of High Density Lipoprotein-Cholesterol (HDL-C). Moreover, a remarkable increase in the Malondialdehyde (MDA) concentration, xanthine oxidase activity, the activity of some liver enzymes, the level of glucose and the concentrations of Total Cholesterol (TC), Triglycerides (TG), low density- and very low density lipoprotein-cholesterol was observed in y-irradiated rats. In contrast, administration of Mulberry Fruit Powder (MFP) to $y$-irradiated rats was found to offer protection against $y$-irradiation induced oxidative stress, by elevating the activity of antioxidant enzymes, enhancing liver function, in addition to improving the lipid metabolism. All results in this study suggested that mulberry fruit had high potential to be developed as radio protective agent.
\end{abstract}

Keywords: Gamma-irradiation; Mulberry fruits; Antioxidants; Insulin; Testosterone

\section{Introduction}

All living organisms are exposed to some amount of radiation coming from outer space or emitted from the radioisotopes present in the environment [1]. Radiations are commonly used in a number of medical and industrial situations; however, their prooxidative effects limit their applications [2]. The deleterious effects of ionizing radiation in biological systems are commonly mediated through the generation of Reactive Oxygen Species (ROS) [3], causing oxidative damage in several organs, including testes [4].

The scavenging of free radicals and inhibition of lipid peroxidation has been suggested to be the key target activities for developing successful radioprotection strategies $[5,6]$. Natural antioxidants play a major role by continuously inactivating ROS, to keep only a small amount necessary to maintain normal cell function [7]. Considerable epidemiological evidence has been gathered to suggest an association between consumption of fruits containing antioxidants, and a reduced risk of certain chronic diseases $[8,9]$.

Mulberry (Morus alba L.) belongs to the family Moraceae. Mulberry fruit is widely regarded as a nutritious food, and it can be eaten freshly or widely used in the production of wine, fruit juice, jam and canned food $[10,11]$. Mulberry fruit is not only used as fruit, but also it has been used effectively in natural medicine for the treatment of sore throat, fever, hypertension and anemia [12,13]. Moreover, mulberry fruit is used to protect against liver and kidney damage, strengthen the joints, improves eyesight, and have anti-aging effects $[11,14]$. Anthocyanins and water extracts from mulberry fruit can scavenge free radicals, inhibit Low-Density Lipoprotein (LDL) oxidation, and have beneficial effects on blood lipid and atherosclerosis $[15,16]$.

Therefore, the present study was undertaken to investigate the possible ameliorative effects of mulberry fruits on oxidative damage, resulting from exposure of normal male rats to $\gamma$-radiation.

\section{Materials and Methods}

\section{Materials and plant preparation}

Standard commercial rodent diet and fresh purple-colored mulberry fruits were purchased from the local market (Cairo, Egypt). All berries were dried at $70^{\circ} \mathrm{C}$ for 4 days and grounded to powder [17].

\section{Radiation facility}

Whole body gamma irradiation of rats was performed using a Canadian gamma cell-40, (137Cs) housed at the National Center for Radiation Research and Technology (NCRRT), Cairo, Egypt. The dose rate was $0.43 \mathrm{~Gy} / \mathrm{min}$ at the time of the experiment. Rats were exposed to fractionated dose of $7.5 \mathrm{~Gy} \gamma$-irradiation administered as $2.5 \mathrm{~Gy}$, every other day.

\section{Determination of total phenolic compounds}

The concentration of total phenolic compound was measured by a modified Follin-Ciocalteu colorimetric method [18]. Briefly, a sample diluted was added to a test tube containing $1.58 \mathrm{~mL}$ of distilled water. Folin-Ciocalteu reagent of $100 \mu \mathrm{L}$ was added, and the tube was stirred and allowed to stand at room temperature for $8 \mathrm{~min} .300 \mu \mathrm{L}$ of $\mathrm{Na}_{2} \mathrm{CO}_{3}$ $(7 \%, \mathrm{w} / \mathrm{v})$ was added to the mixture and the absorbance was measured at $765 \mathrm{~nm}$, after $120 \mathrm{~min}$ at room temperature, using a spectrophotometer. The results were expressed as milligram of Gallic Acid Equivalents (GAE) per gram fresh matter of fruit (mg GAE/ $g$ fruit).

Determination of antioxidant activity by the 2,2-Diphenyl-1Picrylhydrazyl (DPPH)

DPPH assay was determined by previously method described

*Corresponding author: Refaat Galal Hamza, Food Irradiation Research Department, National Centre for Radiation Research and Technology (NCRRT), Atomic Energy Authority, Nasr City, Cairo, Egypt, E-mail: refaatghamza@yahoo.com

Received October 22, 2012; Accepted November 19, 2012; Published November 22, 2012

Citation: Hamzaa RG, El Shahat AN, Mekawey HMS (2012) The Antioxidant Role of Mulberry (Morus alba L.) Fruits in Ameliorating the Oxidative Stress Induced in $y$-Irradiated Male Rats. Biochem Anal Biochem 1:122. doi:10.4172/21611009.1000122

Copyright: @ 2012 Hamzaa RG, et al. This is an open-access article distributed under the terms of the Creative Commons Attribution License, which permits unrestricted use, distribution, and reproduction in any medium, provided the original author and source are credited. 
Citation: Hamzaa RG, El Shahat AN, Mekawey HMS (2012) The Antioxidant Role of Mulberry (Morus alba L.) Fruits in Ameliorating the Oxidative Stress Induced in y-Irradiated Male Rats. Biochem Anal Biochem 1:122. doi:10.4172/2161-1009.1000122

Page 2 of 6

[19]. Each sample $(0.5 \mathrm{~mL})$ was added to $0.5 \mathrm{~mL}$ of $0.4 \mathrm{~mm} \mathrm{DPPH}$ (2,2-Diphenyl-1-Picrylhydrazyl) in methanol. The mixture was shaken vigorously and allowed to stand for $30 \mathrm{~min}$; the absorbance of the resulting solution was measured at $517 \mathrm{~nm}$ with a spectrophotometer. Percent inhibition of DPPH radical was calculated for each dilution of berry extract, according to formula: \%inhibition=[(ADPPH-Aplant $) /$ ADPPH)] $\times 100$, where ADPPH is the absorbance value of the DPPH versus blank solution , and Aplant is absorbance value of the sample solution. A lower level of absorbance indicated a stronger radical scavenging activity.

\section{Experimental animals}

Adult male albino rats reared in NCRRT animal house were used in the present experiments. Matched weight animals $(150 \pm 10 \mathrm{~g})$ were selected and housed in plastic cages, under controlled condition, and fed on standard commercial rodent diet.

\section{Experimental design}

Male albino rats were exposed. 24 animals were randomly divided into four groups as follows: Group (C): (control group) rats fed on balanced diet for 6 weeks, Group (MFP): rats fed on balanced diet contained 1\% Mulberry Fruits Powder (MFP), Group (Irr.): (irradiated group) rats were exposed at the 1 st week of the experiment to fractionated $\gamma$-irradiation dose of $7.5 \mathrm{~Gy}$ administered as $2.5 \mathrm{~Gy}$, every other day and fed on balanced diet for 6 weeks, and Group (Irr.+MFP): irradiated rats fed on balanced diet contained $1 \%$ mulberry fruits powder.

At the end of the experiment, animals from each group were sacrificed, $24 \mathrm{hrs}$ post the last dose of treatment. Blood samples were collected though heart puncture, after light anesthesia and allowed to coagulate, and centrifuged to obtain serum for biochemical analysis. Also, liver tissue was removed for biochemical investigation.

\section{Biochemical analysis}

The lipid peroxidation was determined colorimetrically as Malondialdehyde (MDA) [20]. Hepatic Xanthine Oxidase (XO) and Xanthine Dehydrogenase (XDH) (Table 1) were determined according to Kamiaski and Jewezska [21]. Whereas, the value of hepatic Glutathione content (GSH) and the activity of Superoxides Dismutase (SOD) and Catalase (CAT) were measured by the method of Gross et al. [22], Minami and Yoshikawa [23] and Allain et al. [24], respectively. In addition, Total Cholesterol (TC), Triglycerides (TG) and High-Density Lipoprotein-Cholesterol (HDL-C) were determined, according to procedure described by Allain et al. [24], Fossati and Prencipe [25] and Demacker et al. [26], respectively, while low-density lipoprotein cholesterol and very Low-density lipoprotein-cholesterol were evaluated according to Friedwald et al. [27] and Norbert [28] formulas, respectively, by the following equations: LDL-C $(\mathrm{mg} / \mathrm{dl})=$ TC-(TG/5+HDL-C), vLDL $(\mathrm{mg} / \mathrm{dl})=\mathrm{TG} / 5$. The activity of serum Aspartate Transaminase (AST) and Alanine Transaminase (ALT) was estimated according to Reitman and Frankel [29], serum Gamma Glutamyl Transferase (GGT) was assessed according to Rosalk [30], as well as serum Alkaline Phosphatase Activity (ALP) was assessed, according to Kind and King [31]. Total bilirubin was analyzed using the method reported by Malloy and Evelyn [32]. Serum glucose was evaluated by the method of Trinder [33]. Finally, the serum testosterone concentration was measured by the Enzyme Linked Immunosorbent Assay (ELISA), according to the method of Engrall and Pelmann [34], and also insulin hormone level was determined by radioimmunoassay kit supplied by Diasari, Italy.

\begin{tabular}{|l|c|c|c|c|}
\hline Parameters & \multicolumn{1}{|c|}{ C } & MFP & Irr. & Irr.+MFP \\
\hline $\begin{array}{l}\text { MDA } \\
\text { (n mol/ml) }\end{array}$ & $193.27 \pm 3.24^{\mathrm{a}}$ & $181.76 \pm 2.83^{\mathrm{a}}$ & $388.51 \pm 4.72^{\mathrm{c}}$ & $242.53 \pm 4.61^{\mathrm{b}}$ \\
\hline $\begin{array}{l}\mathrm{XO} \\
\text { (mU/mg } \\
\text { protein) }\end{array}$ & $2.44 \pm 0.07^{\mathrm{a}}$ & $2.30 \pm 0.06^{\mathrm{a}}$ & $3.72 \pm 0.07^{\mathrm{c}}$ & $2.56 \pm 0.05^{\mathrm{b}}$ \\
$\begin{array}{l}\mathrm{XDH} \\
\text { (mU/mg } \\
\text { protein) }\end{array}$ & $3.15 \pm 0.16^{\mathrm{a}}$ & $3.19 \pm 0.14^{\mathrm{a}}$ & $1.56 \pm 0.11^{\mathrm{c}}$ & $2.83 \pm 0.13^{\mathrm{b}}$ \\
\hline $\begin{array}{l}\text { GSH } \\
\text { (mg/g tissue) }\end{array}$ & $27.31 \pm 0.92^{\mathrm{a}}$ & $27.73 \pm 0.86^{\mathrm{a}}$ & $15.68 \pm 0.64^{\mathrm{b}}$ & $25.86 \pm 0.75^{\mathrm{a}}$ \\
\hline $\begin{array}{l}\text { SOD } \\
\text { (U/mg pro- } \\
\text { tein) }\end{array}$ & $46.08 \pm 1.06^{\mathrm{a}}$ & $47.10 \pm 0.88^{\mathrm{a}}$ & $30.11 \pm 0.81^{\mathrm{c}}$ & $41.63 \pm 0.74^{\mathrm{b}}$ \\
\hline $\begin{array}{l}\text { CAT } \\
\text { (U/g protein) }\end{array}$ & $3.21 \pm 0.02^{\mathrm{a}}$ & $3.34 \pm 0.02^{\mathrm{a}}$ & $1.79 \pm 0.02^{\mathrm{c}}$ & $2.83 \pm 0.03^{\mathrm{b}}$ \\
\hline
\end{tabular}

Table 1: Effect of MFP supplementation on MDA, Xanthine Oxidoreductase system (XO and $\mathrm{XDH}$ ), GSH, SOD and CAT of $\mathrm{Y}$-irradiated rats.

\begin{tabular}{|l|l|}
\hline \multicolumn{1}{|c|}{ Parameters } & \multicolumn{1}{c|}{ Fresh matter of mulberry fruits } \\
\hline Total phenolics $(\mathrm{mg} \mathrm{GAE} / \mathrm{g})$ & 519.35 \\
\hline Total antioxidant activity $(\mu \mathrm{g} / \mathrm{mL})$ & 232.25 \\
\hline
\end{tabular}

Table 2: The phenolic compounds and total antioxidant activity contents of MF.

\section{Statistical analysis}

Statistical analyses were performed using computer program, Statistical Packages for Social Science (SPSS) [35], and values were compared to each other, using one-way analysis of variance (ANOVA).

\section{Results}

The amount of total phenolic compounds and the total antioxidant activity of Mulberry Fruit (MF) was shown in table 2; the results obtained were that the total phenolic contents was $519.35 \mathrm{mg} \mathrm{GAE} / \mathrm{g}$, while the total antioxidant activity of MF was $232.25 \mu \mathrm{g} / \mathrm{mL}$ fresh matter of fruit.

The data presented in table 1 revealed a significant decrease in the value of hepatic GSH contents and the activity of XDH, SOD, and CAT activity, associated with a significant increase in MDA level and XO activity of rats exposed to $\gamma$-radiation, as compared to the corresponding values of control and all treated groups; while rats receiving MFP after $\gamma$-irradiation exposure had a lower concentration of MDA and XO activity, and higher level of GSH, as well as SOD and CAT activity, than the $\gamma$-radiated group.

As a result of $\gamma$-irradiation exposure, levels of TC, TG, LDL-C and vLDL-C were highly increased, with a significant decrease in HDL-C concentration, as compared with control and all treated groups, while treatment with MFP after $\gamma$-irradiation exposure, minimizing the hyperlipidemic effects of $\gamma$-irradiation by reducing the concentration of TC, TG, LDL-C and vLDL-C, and elevating the level of HDL-C, as compared with irradiated group only.

Also, the results presented in table 3 revealed a significant elevation in the concentration of total bilirubin and the activity of AST, ALT, ALP and GGT in $\gamma$-irradiated group, compared to control; whereas, the level of total bilirubin in addition to the activity of liver enzymes, were decreased in the group of $\gamma$-irradiated rats supplemented with MFP.

Finally, the data summarized in table 4 indicated that exposure of rats to $\gamma$-irradiation resulted in an obvious rising in the glucose concentration, associated with reduction in the level of insulin and testosterone. In contrast, it was noticed that MFP administration after $\gamma$-irradiation exposure reduced the level of glucose, as well as enhanced the level of insulin and testosterone. 
Citation: Hamzaa RG, El Shahat AN, Mekawey HMS (2012) The Antioxidant Role of Mulberry (Morus alba L.) Fruits in Ameliorating the Oxidative Stress Induced in y-Irradiated Male Rats. Biochem Anal Biochem 1:122. doi:10.4172/2161-1009.1000122

Page 3 of 6

\begin{tabular}{|c|c|c|c|c|}
\hline Parameters & C & MFP & Irr. & Irr.+MFP \\
\hline AST (U/ml) & $30.15 \pm 0.45^{a}$ & $29.71 \pm 0.48^{a}$ & $53.27 \pm 0.73^{c}$ & $36.57 \pm 0.83^{b}$ \\
\hline ALT (U/ml) & $23.54 \pm 0.71^{a}$ & $22.92 \pm 0.59^{a}$ & $41.32 \pm 0.62^{c}$ & $28.41 \pm 0.83^{b}$ \\
\hline $\operatorname{ALP}(\mathrm{U} / 100 \mathrm{ml})$ & $8.92 \pm 0.31^{\mathrm{a}}$ & $8.83 \pm 0.45^{\mathrm{a}}$ & $15.87 \pm 0.61^{\mathrm{c}}$ & $11.06 \pm 0.52^{b}$ \\
\hline YGT (U/ml) & $3.96 \pm 0.29^{\mathrm{a}}$ & $3.88 \pm 0.36^{a}$ & $6.48 \pm 0.47^{c}$ & $4.91 \pm 0.52^{b}$ \\
\hline Bilirubin(mg/dl) & $0.58 \pm 0.02^{\mathrm{a}}$ & $0.57 \pm 0.02^{\mathrm{a}}$ & $1.12 \pm 0.03^{c}$ & $0.70 \pm 0.02^{b}$ \\
\hline & met & 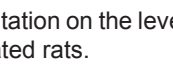 & 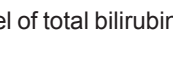 & nd \\
\hline Parameters & C & MFP & Irr. & Irr.+MFP \\
\hline $\begin{array}{l}\text { Glucose } \\
\text { (mg/dl) }\end{array}$ & $111.32 \pm 3.25^{a}$ & $106.81 \pm 3.48^{\mathrm{a}}$ & $149.27 \pm 5.73^{b}$ & $119 \pm 0.83 a^{b}$ \\
\hline $\begin{array}{l}\text { Insulin } \\
(\mu \mathrm{U} / \mathrm{ml})\end{array}$ & $34.85 .54 \pm 2.71^{a}$ & $35.27 \pm 2.59^{a}$ & $20.32 \pm 2.62^{c}$ & $28.95 \pm 2.83^{b}$ \\
\hline $\begin{array}{l}\text { Testosterone } \\
\text { (ng/dl) }\end{array}$ & $202.53 \pm 3.12^{\mathrm{a}}$ & $219.57 \pm 3.12^{\mathrm{a}}$ & $141.63 \pm 2.75^{c}$ & $191.27 \pm 3.03^{b}$ \\
\hline
\end{tabular}

Table 4: Effect of MFP supplementation on glucose, insulin and testosterone of y-irradiated rats.

\begin{tabular}{|l|c|c|c|c|}
\hline Parameters & \multicolumn{1}{|c|}{ C } & MFP & Irr. & Irr.+MFP \\
\hline $\begin{array}{l}\text { TC } \\
(\mathrm{mg} / \mathrm{dl})\end{array}$ & $191.17 \pm 3.11^{\mathrm{a}}$ & $184.31 \pm 2.60^{\mathrm{a}}$ & $260.12 \pm 3.01^{\mathrm{c}}$ & $214.26 \pm 2.57^{\mathrm{b}}$ \\
\hline $\begin{array}{l}\mathrm{TG} \\
(\mathrm{mg} / \mathrm{dl})\end{array}$ & $114.14 \pm 2.14^{\mathrm{a}}$ & $112.54 \pm 1.97^{\mathrm{a}}$ & $184.71 \pm 2.37^{\mathrm{c}}$ & $134.82 \pm 3.11^{\mathrm{b}}$ \\
\hline $\begin{array}{l}\mathrm{HDL}-\mathrm{C} \\
(\mathrm{mg} / \mathrm{dl})\end{array}$ & $51.12 \pm 0.65^{\mathrm{a}}$ & $52.97 \pm 0.91^{\mathrm{a}}$ & $33.36 \pm 0.78^{\mathrm{c}}$ & $45.47 \pm 0.81^{\mathrm{b}}$ \\
\hline $\begin{array}{l}\text { LDL-C } \\
(\mathrm{mg} / \mathrm{dl})\end{array}$ & $117.22 \pm 1.25^{\mathrm{a}}$ & $108.83 \pm 2.11^{\mathrm{a}}$ & $189.82 \pm 2.05$ & $141.83 \pm 2.17^{\mathrm{b}}$ \\
\hline $\begin{array}{l}\text { VLDL-C } \\
(\mathrm{mg} / \mathrm{dl})\end{array}$ & $22.83 \pm 0.11^{\mathrm{a}}$ & $22.51 \pm 0.09^{\mathrm{a}}$ & $36.94 \pm 0.15^{\mathrm{c}}$ & $26.96 \pm 0.12^{\mathrm{b}}$ \\
\hline
\end{tabular}

Table 5: Effect of MFP supplementation on lipid profile of $\mathrm{y}$-irradiated rats.

\section{Discussion}

It is well documented that dietary antioxidants play an important role in mitigating the damaging effects of oxidative stress on cells. Yang et al. [36] indicated that mulberry fruit is a natural health food with antioxidant effects, and these beneficial effects may be because of phytochemical constituents, which might include fiber, fatty acids, phenolics, flavonoids, anthocyanins, vitamins and trace elements.

Many reports have revealed that the physiological function of natural foods can be attributed to the antioxidative capacity of their phenolic components. The results in table 2 demonstrated that the Total Phenolic Content (TPC) of mulberry fruit was $519.35 \mathrm{mg} \mathrm{GAE} / \mathrm{g}$, whereas the total antioxidant activity was $232.25 \mu \mathrm{g} / \mathrm{mL}$, and these results were in agreement with Kaewkaen et al. [17].

According to the data obtained, it appears that the detrimental damage of radiation is associated with the alteration of XOR system, and conversion of XDH into XO activity. The significant increase in $\mathrm{XO}$ activity might be attributed to radiation-induced hypoxia, where insufficient oxygen availability elevates calcium concentration, which activates a protease capable of converting the dehydrogenase to oxidase form $[37,38]$. Also, the level of MDA in the present study was elevated in the serum of untreated irradiated animals. The observed increased Thiobarbituric Acid Reactive Substances (TBARS) level in irradiated rats could be attributed to the peroxidation of membranes lipid, resulted in cellular structure modifications and oxygen radicals-mediated tissue damage $[39,40]$.

In the present study, the activities of Superoxide Dismutase (SOD) and Catalase (CAT) were significantly decreased in irradiated rats. The existence of a mutually supportive relationship between enzymatic antioxidants; SOD and CAT against accumulation of ROS inactivates the superoxide anion and peroxide radicals, by converting them into water and oxygen. In this study, the observed decrease in SOD activity suggests inactivation of the enzyme, possibly due to increased superoxide radical production or an inhibition by the $\mathrm{H}_{2} \mathrm{O}_{2}$, as a result of corresponding decrease in the activity of CAT, which selectively degrades $\mathrm{H}_{2} \mathrm{O}_{2}$. In previous studies, activities of SOD, CAT and GPx have been reported to decrease in the liver of irradiated rats [41,42]. The significant decrease in GSH levels observed in untreated irradiated animals may lead to decreased protection against oxidants. This decrease could be due to an enhanced utilization in large amount, to combat the radiation-induced free radical damage, as glutathione is a major non-enzymatic antioxidant [43]. Similar decrease in hepatic GSH [40], and testicular GSH has been reported, following gamma irradiation in rats [44].

In this study, irradiated rats treated with Mulberry Fruits Powder (MFP) showed a significant decrease in the level of MDA content and $\mathrm{XO}$ activity, with concomitant significant increase in the activity of XDH, SOD and CAT, and in the content of GSH. Thus, MFP has potential as an anti-peroxidative agent, and as an antioxidant. Yang et al. [36] reported that MFP contained vitamin C and low levels of vitamin $\mathrm{E}$, in addition to anthocyanins and flavonoids; all of which are powerful natural antioxidants that increase SOD and GSH-Px activities, and decrease TBARS concentration and improve lipid profiles in rats $[45,46]$. In addition, mulberry fruit contains many trace elements including $\mathrm{Cu}, \mathrm{Mn}, \mathrm{Zn}$ and $\mathrm{Fe}$, which are necessary components of SOD [37]. Among these, $\mathrm{Cu}, \mathrm{Mn}$ and $\mathrm{Fe}$ are prosthetic groups of SOD and play a decisive role in its enzyme activity. $\mathrm{Zn}$ stabilizes the structure of SOD [47]. Se is an important element of GSH-Px, which regulates lipid metabolism, prevents fatty liver formation, and improves antioxidant ability in rats [48].

The present results revealed that the levels of TC, TG, LDL and vLDL-C in serum were significantly higher in irradiated rats, than those of the control group. On the other hand, radiation exposure resulted in a significant decrease in HDL-C level in serum of the irradiated rats. Significant increase in the levels of serum lipid profile and LDL are demonstrated post radiation exposure of rats (Table 5), possibly as a result of liver injury. This indicates that ionizing-radiation-induced oxidative stress, which might alter hepatic lipid metabolism and serum lipoproteins. It seems that there is an association between radiationinduced oxidative stress and elevated levels of lipid fractions and LDL [49]. This association is similarly observed in other conditions, characterized by increased oxidative stress [50,51]. Therefore, it is suggested that oxidative stress might be an important determinant of altered lipid metabolism, due to radiation exposure [52].

Administration of MFP to irradiated rats resulted in significant declines in serum lipid profile, LDL-C and vLDL-C, associated with remarkable elevation in HDL-C, as compared to $\gamma$-irradiated group. The physiological effects of mulberry as antioxidant take place via its content like flavonoid, therefore suggesting their role in prevention of coronary heart disease [53], including atherosclerosis. Wan et al. [53] and Jenkins et al. [54] reported that flavonoids may decrease the risk of cardiovascular disease by lowering LDL: HDL ratio and reducing oxidized LDL in human, and make LDL less susceptible to oxidative stress. Flavonoids may work by making liver cells more efficient, to remove LDL-C from blood by increasing the LDL receptor densities in liver, and by binding to apolipoprotein $\mathrm{B}[55,56]$. Also, the increase in HDL-C concentration could protect the LDL against oxidation in vivo because lipids in HDL are preferentially oxidized, before those in LDL [57].

The activities of ALT, AST, ALP and GGT, as well as the level of total bilirubin in serum, showed a significant rise, following $\gamma$-irradiation exposure. The increase in aminotransferase activities by radiation may be due to the damage of cellular membranes of hepatocytes, which in 
Citation: Hamzaa RG, El Shahat AN, Mekawey HMS (2012) The Antioxidant Role of Mulberry (Morus alba L.) Fruits in Ameliorating the Oxidative Stress Induced in y-Irradiated Male Rats. Biochem Anal Biochem 1:122. doi:10.4172/2161-1009.1000122

turn, leads to an increase in the permeability of cell membranes, and facilitates the passage of cytoplasmic enzymes outside the cells, leading to the increase in the aminotransferase activities in liver and blood serum [58,59]. Also, it is proposed that oxidative stress is linked to the organ damage, following exposure to ionizing radiation $[52,60]$.

However, the activity of liver enzymes was decreased, as a result of MFP administration to $\gamma$-irradiated rats. Several studies revealed that mulberry fruit, leaves, bark and branches have been used in Chinese medicine to treat fever, facilitate discharge of liver, protect the liver damage and lower blood pressure $[61,62]$. Hsu et al. [63] investigated the protective mechanisms of Mulberry Water Extracts (MWEs) in carbon tetrachloride (CCl4)-induced hepatic injury, and observed that the levels of serum Aspartate Aminotransferase (AST), Alanine Aminotransferase (ALT), and Alkaline Phosphatase (ALP) were reduced via cotreatment with MWEs, compared with CCl4 treatment alone. Also, the authors concluded that MWEs exhibit protective and curative effects against CCl4-induced liver damage and fibrosis, via decreased lipid peroxidation and inhibited proinflammatory gene expression.

In this study, rats exposed to gamma radiation had a significant elevation in serum glucose level and noticeable reduction in insulin concentration, compared to the control group. Ellefson and Caraway [64] stated that hyperglycemia may be caused by metabolic disorder, as a result of endocrine dysfunction and increased level of glucose. The recorded hyperglycemia in the present results could be attributed to endocrine abnormalities induced by irradiation, that promote the secretion of peptide which has relation to carbohydrate metabolism, by increasing glyconeogenesis in liver $[65,66]$. Lee et al. [67] and Hamza and Osman [68] attributed the lowering effect of $\gamma$-irradiation exposure on insulin level to the production of free radicals that induced oxidative stress, resulted in reduction in insulin secretion and DNA damage.

Results of $\gamma$-irradiated rats receiving MFP revealed an obvious reduction in glucose level and elevation in insulin concentration, in comparison to $\gamma$-irradiated group. The antidiabetic activities of mulberry leaf extract in experimental animals have also been reported by many researchers $[69,70]$, with the studies supporting the usage of mulberry reduced blood glucose in rats with diabetes, induced by streptozotocin or alloxan [71-73]. In addition, mulberry has long been used in Chinese medicine for the prevention and treatment of diabetes, because as we now know, they contain chemical compounds that suppress high blood sugar levels (hyperglycemia), following a carbohydrate-rich meal. Mudra et al. [74] concluded that the co-ingestion of mulberry extract with $75 \mathrm{~g}$ sucrose significantly reduced the increase in the blood glucose level. Moreover, Liu et al. [75] observed a significant decline in blood glucose, accompanied with evident increase in plasma insulin level in diabetic mice treated with the hybrid of 1-deoxynojirimycin and polysaccharide (HDP) from mulberry. The authors reported that HDP could protect pancreatic $\beta$-cells from damage induced by alloxan, due to the ability to scavenge the free radical and repair the destroyed pancreatic $\beta$-cells, and restored the serum insulin in HDP treated mice to normal.

In this study, a significant reduction in the concentration of testosterone was observed, as a result of $\gamma$-irradiation exposure. In contrast, the value of this hormone was obviously increased, post treatment of $\gamma$-irradiated rats with MFP. Liu et al. [75] and Michael and Amer [76] found that the level of testosterone was decreased after whole-body irradiation dose of 4 and 5 Gy due to alterations in DNA-single strand break, cell apoptosis and oxidative stress. Popoff and Kapich [77] observed a positive correlation between a decline in testosterone affinity and exposure to gamma irradiation. Also, Oi-Kano et al. [78] reported that $\gamma$-irradiation exposure (6 Gy) resulted in a significant decline in testosterone concentration due to generation of free radicals.

However, the effect of MFP on testosterone level might be attributed to its phenolic contents that have antioxidant capacity, and prevent oxidative damage induced by $\gamma$-irradiation. Jeong et al. [79] proposed the mechanism of phenolic compounds, whose supplementation enhances lipid and protein metabolism, owing to hormonal regulation by the stimulation of noradrenalin secretion, thereby affecting the levels of steroid hormones, including testosterone and corticosterone, and other hormones in rats. Also, the effect of MFP could be linked to the abundance of flavonoids (which is an effective aromatase inhibitor) [79]. The cytochrome P-450 aromatase is required for the conversion of androgens to estrogens, and hence, aromatase inhibitors would decrease the concentration of estrogens and maintain a higher level of testosterone.

\section{Conclusion}

In conclusion, the present study revealed that the mulberry fruit is the potential functional food that can protect against oxidative damage induced by gamma-irradiation in male rats, through its positive effects on the activity of some antioxidant enzymes, liver enzymes, elevation of the level of insulin and testosterone, inhibition of lipid peroxidation, as well as improvement of lipid profile. Moreover, the ameliorating effects of MF attributed to its phenolic and flavonoid contents that possess antioxidant activity.

\section{Acknowledgement}

Authors are grateful to their colleague at the Food Irradiation Department, Safaa Afifi Mohamed, for her help and support to carry out this work.

\section{References}

1. Kumar S (2004) Occupational exposure associated with reproductive dysfunction. J Occup Health 46: 1-19.

2. El-Missiry MA, Fayed TA, El-Sawy MR, El-Sayed AA (2007) Ameliorative effect of melatonin against gamma-irradiation-induced oxidative stress and tissue injury. Ecotoxicol Environ Saf 66: 278-286.

3. Kamat JP, Boloor KK, Devasagayam TP, Venkatachalam SR (2000) Antioxidant properties of Asparagus racemosus against damage induced by gammaradiation in rat liver mitochondria. J Ethnopharmacol 71: 425-435.

4. Adedara IA, Farombi EO (2010) Induction of oxidative damage in the testes and spermatozoa and hematotoxicity in rats exposed to multiple doses of ethylene glycol monoethyl ether. Hum Exp Toxicol 29: 801-812.

5. Hosseinimehr SJ, Shafiee A, Mozdarani H, Akhlagpour S (2001) Radioprotective effects of 2-iminothiazolidine derivatives against lethal doses of gamma radiation in mice. J Radiat Res 42: 401-408.

6. Fani A, Malekirad AA, Fani I, Allahnazem H, Rahzani K, et al. (2008) On the benefit of Cinnamonum zeylanicum for radiology unit staff. J Med Sci 8: 384389

7. Oyagbemi AA, Adedara IA, Saba AB, Farombi EO (2010) Role of oxidative stress in reproductive toxicity induced by coadministration of chloramphenicol and multivitamin-haematinics complex in rats. Basic Clin Pharmacol Toxicol 107: $703-708$

8. Record IR, Dreosti IE, Mcinerney JK (2001) Changes in plasma antioxidant status following consumption of diets high or low in fruit and vegetables or following dietary supplementation with an antioxidant mixture. $\mathrm{Br} \mathrm{J}$ Nutr 85 459-464.

9. Voutilainen S, Nurmi T, Mursu J, Rissanen TH (2006) Carotenoids and cardiovascular health. Am J Clin Nutr 83: 1265-1271.

10. Ning DW, Lu B, Zhang YL (2005) The processing technology of mulberry series product. China Fruit Vegetables Process 5: 38-40. 
Citation: Hamzaa RG, El Shahat AN, Mekawey HMS (2012) The Antioxidant Role of Mulberry (Morus alba L.) Fruits in Ameliorating the Oxidative Stress Induced in y-Irradiated Male Rats. Biochem Anal Biochem 1:122. doi:10.4172/2161-1009.1000122

Page 5 of 6

11. Wattanathorn J, Muchimapura S, Thukhammee W, Tong-un T, Wannanon P, et al. (2012) Mulberry Fruits Protects Against Age-Related Cognitive Decline. American Journal of Applied Sciences 9: 1503-1511.

12. Ma YP (2002) Clinical observation of mulberry as a medicine of pharyngitis treatment. Xinjiang J Traditional Chinese Med 20: 83-84.

13. Gong SX, Zhu JP (2008) Mulberry relieving nutritional anemi. J Zhejiang Univ Traditional Chinese Med 32: 350-352.

14. Shizhen L (2008) Compendium of Materia Medica. (1st Edn), Foreign Language Press, ISBN-10: 71190326074400

15. Chen CC, Liu LK, Hsu JD, Huang HP, Yang MY, et al. (2005) Mulberry extract inhibits the development of atherosclerosis in cholesterol-fed rabbits. Food Chem 91: 601-607

16. Du Q, Zheng J, Xu Y (2008) Composition of anthocyanins in mulberry and their antioxidant activity. J Food Compost Anal 21: 390-395.

17. Kaewkaen P, Tong-Un T, Wattanathorn J, Muchimapura S, Kaewrueng W, et al. (2012) Mulberry Fruit Extract Protects against Memory Impairment and Hippocampal Damage in Animal Model of Vascular Dementia. Evid Based Complement Alternat Med 2012: 263520.

18. Tsantili E, Shin Y, Nock JF, Watkins CB (2010) Antioxidant concentrations during chilling injury development in peaches. Postharvest Biol Technol 57 27-34.

19. Jakobek L, Seruga M, Medvidovic-Kosanovi M, Novak I (2007) Antioxidant activity and polyphenols of Aronia in comparison to other berry species. Agric Conspectus Sci: 301-306.

20. Yoshioka T, Kawada K, Shimada T, Mori M (1979) Lipid peroxidation in materna and cord blood and protective mechanism against activated-oxygen toxicity in the blood. Am J Obstet Gynecol 135: 372-376.

21. Kaminski ZW, Jezewska MM (1979) Intermediate dehydrogenase-oxidase form of xanthine oxidoreductase in rat liver. Biochem $\mathrm{J}$ 181: 177-182.

22. Gross RT, Bracci R, Rudolph N, Schroeder E, Kochen JA (1967) Hydrogen peroxide toxicity and detoxification in the erythrocytes of newborn infants. Blood 29: 481-493.

23. Minami M, Yoshikawa $H$ (1979) A simplified assay method of superoxide dismutase activity for clinical use. Clin Chim Acta 92: 337-342.

24. Allain CC, Poon LS, Chan CS, Richmond W, Fu PC (1974) Enzymatic determination of total serum cholesterol. Clin Chem 20: 470-475.

25. Fossati P, Prencipe L (1982) Serum triglycerides determined colorimetrically with an enzyme that produces hydrogen peroxide. Clin Chem 28: 2077-2080.

26. Demacker P, Vos-janssen H, Hifman A, Vants Lear A, Jansen A (1980) Measurement of high density lipoprotein cholesterol in serum. Clin Chem 26 : 1780

27. Friedewald WT, Levy RI, Fredrickson DS (1972) Estimation of the concentration of low-density lipoprotein cholesterol in plasma, without use of the preparative ultracentrifuge. Clin Chem 18: 499-502.

28. Norbert WT (1995) Clinical Guide to Laboratory Tests (Third ed), Saunders W.B. Company, Philadelphia.

29. Reitman S, Frankel S (1957) A colorimetric method for the determination of serum glutamic oxalacetic and glutamic pyruvic transaminases. Am J Clin Pathol 28: 56-63.

30. Rosalk SB (1657) In advances clinical chemistry. Academic Press Chap 17: 53

31. Kind PR, King EJ (1954) Estimation of plasma phosphatase by determination of hydrolysed phenol with amino-antipyrine. J Clin Pathol 7: 322-326.

32. Malloy HT, Evelyn KA (1937) The Determination of bilirubin with the photoelectric colorimeter. J Biol Chem 119: 481-490.

33. Trinder $P$ (1969) Enzymatic colorimetric determination of glucose. Ann Clin Biochem 6: 24 C/F, Bio Merieux Comp, France.

34. Engrall E, Pelmann P (1971) Qualitative enzyme linked immunoassary. Immuno chem 8: 871

35. SPSS (1998) Statistical Package for Social Science. Computer Software, Ver 10. SPSS Company, London, UK.

36. Yang X, Yang L, Zheng H (2010) Hypolipidemic and antioxidant effects of mulberry (Morus alba L.) fruit in hyperlipidaemia rats. Food Chem Toxicol 48: 2374-2379.
37. Saada HN, Rezk RG, Eltahawy NA (2010) Lycopene protects the structure of the small intestine against gamma-radiation-induced oxidative stress. Phytother Res 24: S204-S208.

38. Leyko W, Bartosz G (1986) Membrane effects of ionizing radiation and hyperthermia. Int J Radiat Biol Relat Stud Phys Chem Med 49: 743-770.

39. Azab KSh, Mostafa AH, Ali EM, Abdel-Aziz MA (2011) Cinnamon extract ameliorates ionizing radiation-induced cellular injury in rats. Ecotoxicol Environ Saf 74: 2324-2329.

40. Dubner D, Gisone P, Jaitovich I, Perez M (1995) Free radicals production and estimation of oxidative stress related to gamma irradiation. Biol Trace Elem Res 47: 265-270.

41. Mansour HH, Hafez HF, Fahmy NM, Hanafi N (2008) Protective effect of $\mathrm{N}$-acetylcysteine against radiation induced DNA damage and hepatic toxicity in rats. Biochem Pharmacol 75: 773-780.

42. Reiter RJ, Tan DX, Manchester LC, Qi W (2001) Biochemical reactivity of melatonin with reactive oxygen and nitrogen species: a review of the evidence. Cell Biochem Biophys 34: 237-256.

43. Adaramoye OA, Adedara IA, Farombi EO (2012) Possible ameliorative effects of kolaviron against reproductive toxicity in sub-lethally whole body gammairradiated rats. Exp Toxicol Pathol 64: 379-385.

44. Yan XH (2000) The effects on serum and lipids peroxidation state of soy isoflavones. Nutr J 22: 31-35.

45. Toyokuni S, Tanaka T, Kawaguchi W, Fang NRL, Ozeki M, et al. (2003) Effects of the phenolic contents of Mauritian endemic plant extract on promoter activities of antioxidant enzymes. Free Radic Res 37: 1215-1224.

46. Mei GQ, Ying H (2003) Chemical behavior and biological effect on trace elements among three superoxide dismutases. Stud. Trace Elem Health 20 : 59-62

47. Zhou CY, Ran L, Zhang X (2004) The effects on the serum lipids, fatty liver and lipid peroxidation of vitamin $\mathrm{E}$ in experimental hyperlipemia rats. China Clin Pharmacol Therapeut 9: 202-215.

48. Onody A, Csonka C, Giricz Z, Ferdinandy P (2003) Hyperlipidemia induced by a cholesterol-rich diet leads to enhanced peroxynitrite formation in rat hearts Cardiovasc Res 58: 663-670.

49. Baynes JW (1991) Role of oxidative stress in development of complications in diabetes. Diabetes 40: 405-412.

50. El-Missiry MA, Othman Al, Amer MA (2004) L-Arginine ameliorates oxidative stress in alloxan-induced experimental diabetes mellitus. J Appl Toxicol 24: 9397.

51. Makhlouf R, Makhlouf I (2012) Evaluation of the effect of Spirulina against Gamma irradiation induced oxidative stress and tissue injury in rats. Int Journal of Applied Sciences and Engineering Research 1: 152-164.

52. Sierens J, Hartley JA, Campbell MJ, Leathem AJ, Woodside JV (2002) In vitro isoflavone supplementation reduces hydrogen peroxide-induced DNA damage in sperm. Teratog Carcinog Mutagen 22: 227-234.

53. Wan Y, Vinson JA, Etherton TD, Proch J, Lazarus SA, et al. (2001) Effects of cocoa powder and dark chocolate on LDL oxidative susceptibility and prostaglandin concentrations in humans. Am J Clin Nutr 74: 596-602.

54. Jenkins DJ, Kendall CW, Jackson CJ, Connelly PW, Parker T, et al. (2002) Effects of high- and low-isoflavone soyfoods on blood lipids, oxidized LDL, homocysteine, and blood pressure in hyperlipidemic men and women. Am J Clin Nutr 76: 365-372.

55. Haslam E (1981) Plant Polyphenols. Cambridge University Press, Cambridge, United Kingdom, 154-195.

56. Baum JA, Teng H, Erdman JW, Weigel RM, Klein BP, et al. (1998) Long term intake of soy protein improves blood lipid profile and increases mononuclear cell low density lipoprotein receptor messenger RNA in hypercholesterolemic postmenopausal women. Am J of Clin Nut 58: 545-551.

57. Bowry VW, Stanley KK, Stocker R (1992) High density lipoprotein is the majo carrier of lipid hydroperoxides in human blood plasma from fasting donors. Proc Natl Acad Sci U S A 89: 10316-10320.

58. Ramadan LA, Roushdy HM, Abu Senna GM, Amin NE, EIDeshw OA (2002) Radioprotective effect of silymarin against radiation induced hepatotoxicity. Pharmacol Res 45: 447-454. 
Citation: Hamzaa RG, El Shahat AN, Mekawey HMS (2012) The Antioxidant Role of Mulberry (Morus alba L.) Fruits in Ameliorating the Oxidative Stress Induced in y-Irradiated Male Rats. Biochem Anal Biochem 1:122. doi:10.4172/2161-1009.1000122

59. Ali SA, Fadda LM, Elebiary H, Soliman M (2012) Evaluation of the radioprotective action of anserine along with zinc in albino rats exposed to gammaradiation. $J$ of Appl Pharmaceutical Sci 2: 115-122.

60. Halliwell B, Whiteman M (2004) Measuring reactive species and oxidative damage in vivo and in cell culture: how should you do it and what do the results mean? Br J Pharmacol 142: 231-255.

61. Zhishen J, Mengcheng T, Jianming W (1999) The determination of flavonoid contents in mulberry and their scavenging effects on superoxide radicals. Food Chem 64: 555-559.

62. Hwang J-Y, W-C Sung and Y-S Shyu (2008) Effect Of Mulberry Lees Addition On Dough Mixing Characteristics and the Quality Of Mulberry Toast. J of Marine Sci and Technol 16: 103-108.

63. Hsu LS, Ho HH, Lin MC, Chyau CC, Peng JS, et al. (2012) Mulberry water extracts (MWEs) ameliorated carbon tetrachloride-induced liver damages in rat. Food Chem Toxicol 50: 3086-3093.

64. Ellefson RD, Caraway WT (1976) Lipids and lipoproteins In: Fundamentals in clinical chemistry, edited by Tietz, 474-541.

65. Darwish MM, Hussien EM, Haggag AM (2007) Possible role of licorice roots (glycyrrhiza glabra) as a natural radioprotector against oxidative damage in rats. Egypt J Rad Sci Applic 20: 95-108.

66. Ramadan FL (2007) Evaluation of the synergistic effect of danazol and radiation exposure on some biochemical functions in female albino rats. The Egyptian Journal of Hospital Medicine 27: 255-262

67. Lee TK, O'Brien KF, Wang W, Johnke RM, Sheng C, et al. (2010) Radioprotective effect of American ginseng on human lymphocytes at 90 minutes postirradiation: a study of 40 cases. J Altern Complement Med 16: 561-567.

68. Hamzaa RG, Osman NN (2012) Using of Coffee and Cardamom Mixture to Ameliorate Oxidative Stress Induced in ?-irradiated Rats. Biochem Anal Biochem 1: 113.

69. Andallu B, Suryakantham V, Lakshmi Srikanthi B, Reddy GK (2001) Effect of mulberry (Morus indica $L$.) therapy on plasma and erythrocyte membrane lipids in patients with type 2 diabetes. Clin Chim Acta 314: 47-53

70. Li YG, Ji DF, Zhong S, Lv ZQ, Lin TB, et al. (2011) Hybrid of 1-deoxynojirimycin and polysaccharide from mulberry leaves treat diabetes mellitus by activating PDX-1/insulin-1 signaling pathway and regulating the expression of glucokinase, phosphoenolpyruvate carboxykinase and glucose-6-phosphatase in alloxan-induced diabetic mice. J of Ethnopharmacol 134: 961-970.

71. Miyahara C, Miyazawa M, Satoh S, Sakai A, Mizusaki S (2004) Inhibitory effects of mulberry leaf extract on postprandial hyperglycemia in normal rats. $J$ Nutr Sci Vitaminol (Tokyo) 50: 161-164.

72. Chen F, Nakashima N, Kimura I, Kimura M (1995) Hypoglycemic activity and mechanisms of extracts from mulberry leaves (folium mori) and cortex mor radicis in streptozotocin-induced diabetic mice. Yakugaku Zasshi 115: 476-482.

73. Ye F, Shen ZF, Qiao FX, Zhao DY, Xie MZ (2002) Experimental treatment of complications in alloxan diabetic rats with alpha-glucosidase inhibitor from the Chinese medicinal herb ramulus mori. Yao Xue Xue Bao 37: 108-112.

74. Mudra M, Ercan-Fang N, Zhong L, Furne J, Levitt M (2007) Influence of mulberry leaf extract on the blood glucose and breath hydrogen response to ingestion of $75 \mathrm{~g}$ sucrose by type 2 diabetic and control subjects. Diabetes Care 30: 1272-1274

75. Liu Y, Zhang H, Zhang L, Zhang X, Xie Y, et al. (2009) Melatonin modulates acute testicular damage induced by carbon ions in mice. Pharmazie 64: 685689

76. Michael MI, Amer MM (2010) Is the use of antioxidants mixture ameliorating the double stress effect of radiation and hyperlpidemia? J Rad Res Appl Sci 3: $855-874$.

77. Popoff EH, Kapich AN (2010) The effect of ionising radiation on testosterone binding globulin characteristics: correction of the protein' parameters by lipid polyene complexes of fungus Laetiporus sulfureus. Int J Radiat Biol 86: 238251.

78. Oi-Kano Y, Kawada T, Watanabe T, Koyama F, Watanabe K, et al. (2012) Oleuropein supplementation increases urinary noradrenaline and testicular testosterone levels and decreases plasma corticosterone level in rats fed highprotein diet. J Nutr Biochem.

79. Jeong HJ, Shin YG, Kim IH, Pezzuto JM (1999) Inhibition of aromatase activity by flavonoids. Arch Pharm Res 22: 309-312. 